\title{
SPATIAL PLANNING AS AN INSTRUMENT FOR TOURISM DEVELOPMENT IN PROTECTED NATURAL AREAS - EXAMPLE OF SPECIAL NATURE RESERVE UVAC, SERBIA
}

\author{
Velimir Šećerov ${ }^{60}$ \\ Dejan Filipović61 \\ Branko Protićc 6
}

https://doi.org/10.31410/itema.2018.154

\begin{abstract}
Tourism development produces various positive and negative effects in the planning and management of protected areas, especially in vulnerable and sensitive areas that are under increased pressure from visitors. Spatial planning, which is based on adequate spatial development in accordance with environmental protection, as well as projections of the volume and structure of tourist demand, aims at integral observation of tourism in accordance with the possibilities and characteristics of the area. It represents the only means for resolving developmental contradictions between nature and tourism, aims to transform this conflict into a positive/sustainable direction of interdependence between tourism development and nature protection.

The paper deals with the problem of sustainable tourism development in the Special Nature Reserve "Uvac", relying on the solutions defined in the Spatial Plan of the Special Purpose Area of the Special Nature Reserve Uvac (SPSPA SNR Uvac). The Special Nature Reserve Uvac represents a natural good of exceptional importance (natural good of the first category). The tendency has been that through planning solutions and propositions, to solve the active problems, define clearer tourist products and prioritize activities in short and long term future. The results presented in this paper will contribute to better understanding of the problems, limitations, but also opportunities for sustainable tourism development in this and other protected areas.
\end{abstract}

Keywords: tourism development, spatial planning, protected natural area, conflicts, sustainable development

\section{INTRODUCTION}

$\mathrm{I}$ $\mathrm{n}$ the Republic of Serbia, the spatial plan, as a multidisciplinary complex document, defines: objectives, strategic development determinations, rules and regimes of protection, arrangement, and use of space, position and capacities of priority tourist sites in accordance with the quality of resources and the possibility of rational infrastructural equipping, phases, measures, and instruments of implementation, as well as the need for further elaboration by appropriate urban plans and programs.

Spatial planning is promoted as one of the instruments of sustainable development that can offer integrated territorial development, whose basic task is the planning of sustainable territorial development as a general strategic framework for general and sectoral policies [1]. In strategic

\footnotetext{
${ }^{60}$ University of Belgrade - Faculty of Geography, Studentski trg 3/III, Belgrade, Serbia

${ }^{61}$ University of Belgrade - Faculty of Geography, Studentski trg 3/III, Belgrade, Serbia

${ }^{62}$ University of Belgrade - Faculty of Geography, Studentski trg 3/III, Belgrade, Serbia
} 
planning and direction of the sustainable development of tourist areas and centers, spatial and environmental planning have an integrative role that manifests itself through spatial planning and environmental quality management [2], [3].

The research subject in this paper is Spatial Plan for Special Purpose Area of the Special Nature Reserve Uvac (SPSPA SNR Uvac) with a special emphasis on the concept of tourism development proposed in this plan. The aim of the paper is to point out the importance and role of the spatial plan as an instrument for tourism development, following the example of the Special Nature Reserve Uvac (SNR Uvac). The research results can serve as a basis (starting point) for planning development in similar areas.

\section{STUDY AREA}

The area of the SNR Uvac is located in the far southwestern part of Serbia and partly borders with Montenegro. In regional-geographical terms, the planned area belongs to the area of Stari Vlah, and, in administrative terms, to Zlatibor, Moravica, and Raška administrative districts.

The subject of analysis in this paper is the Spatial Plan for Special Purpose Area of the SNR Uvac, which includes the area of the SNR Uvac with its protected zone (Figure 1). The protected zone of SNR Uvac covers the Uvac River basin around the protected area of the SNR Uvac upstream from the Radoinja water dam profile and the Boroštica river basin on Pešter Field. 
Figure 1: The area covered by Spatial Plan for Special Purpose Area of the SNR Uvac

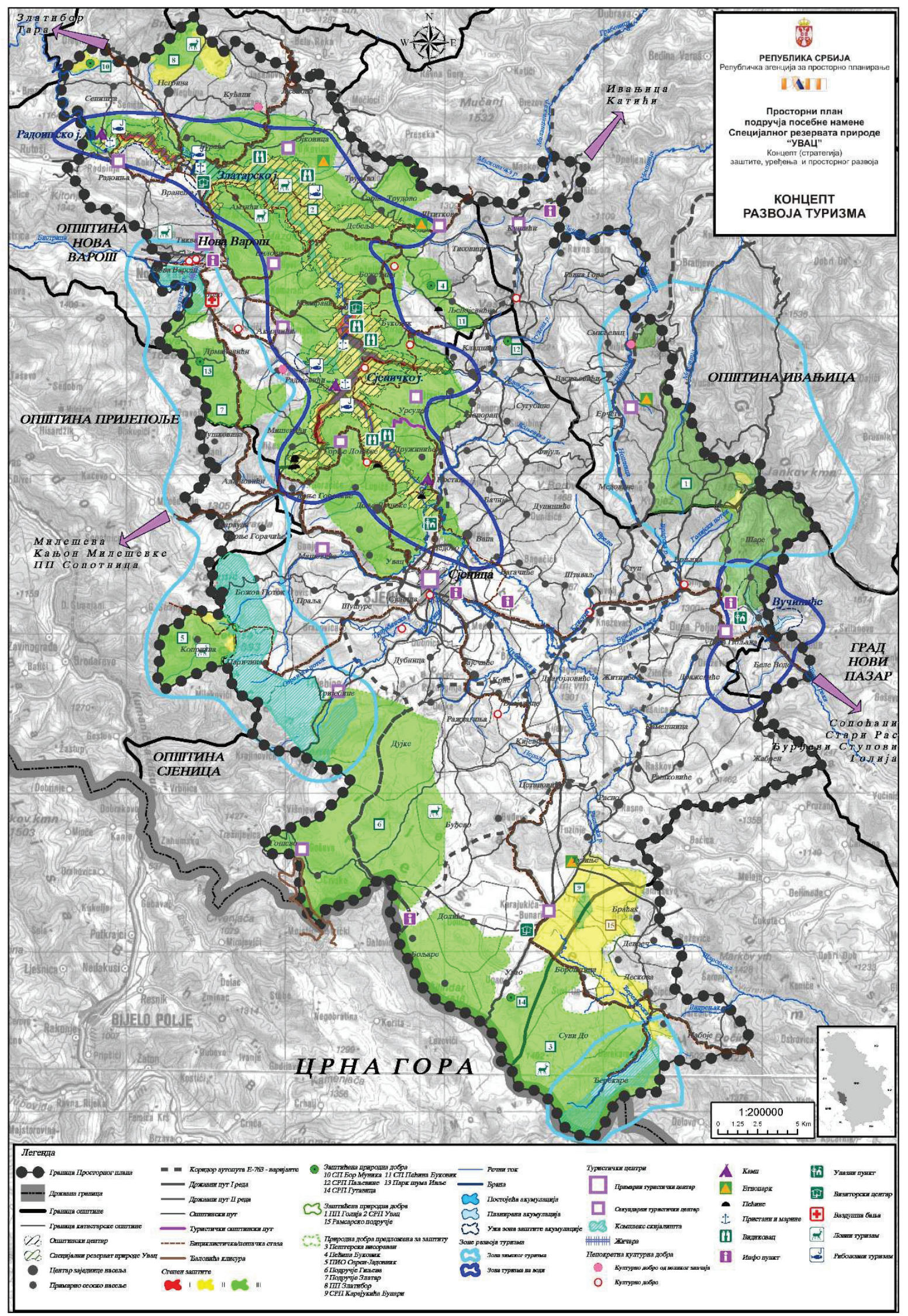

(Source: SPSPA SNR Uvac, 2010) 


\section{POTENTIALS, LIMITATIONS AND OBJECTIVES OF TOURISM DEVELOPMENT}

Potentials of the planned area for tourism development are: water wealth (lakes, watercourses, springs and karst springs, groundwater, mineral springs); the existing network of I and II class state roads, and the planned Belgrade-South Adriatic highway and the Belgrade-Bar railway in the immediate vicinity of the area; diverse flora and fauna (griffon vulture population, etc.); natural resources proclaimed and envisaged for protection (Uvac, Pešter Field, etc.); diverse, representative, and attractive relief elements (curved meanders of Uvac); Đalović gorge, Pešter Plateau, etc.; three large speleological structures (Ušačka, Ledena, and Tubića caves); cultural goods; high-quality and competent staff of the SNR Uvac administrator; good geo-strategic location of the area and attractive wider, regional, tourist context; rich ethnological capacities (tradition, events, crafts, cuisine, customs, etc.); private initiative and privatization of accommodation facilities.

The basic problems and limitations of the planned area for tourism development are: low level of area protection and development management; ecological problems - the unresolved issue of waste communal waters coming from settlements, Sjenica landfill and numerous solid waste dumps, disposal and elimination of wood processing waste; disorder and lack of equipment of public spaces and facilities for visitors' stay and recreation, lack of visitor centers; low level of accessibility to attractive tourist sites; low level of utility equipment, uncompleted technical infrastructure and lack of coverage of public roads with modern roadway; low level of marketing penetration onto the national and European market; illegal construction; lack of regional cooperation - local understanding of development; abandoned accommodation facilities; unfinished hotel privatization; lack of unique tourist offer within and outside of SNR Uvac [4], [6].

\subsection{Objectives}

The main objective is tourism development in line with the requirements of preserving and improving the quality of the environment and preserving natural values and resources, as well as tourism development in line with interests and stimulating the development of local communities, primarily communities in the rural areas [4].

The specific objectives of tourism development are:

- Integrating the tourist offer of the area with the regional offer and development of specific tourist products according to the requirements of foreign and domestic tourist demand;

- Conceiving, organizing, promotion, and completion of specific tourist offer and attractive programs in the planned area;

- Increasing traffic accessibility and interconnecting tourist areas in order to unify and secure all-year tourism offer;

- Completion of public utility and tourist infrastructure for the needs of tourism development and increasing service standards of existing and planned tourist capacities;

- Initiating and stimulating the development of complementary tourism activities;

- Activation of the local population in the rural area and their housing fund for tourism development [4]. 


\section{MAIN CONFLICTS IN THE AREA OF SNR UVAC}

For the planning and implementation of protection and sustainable development of the area of SNR Uvac, it is necessary to establish a strategy for reducing the opposing interests of sustainable protection of strategic natural resources and natural values in relation to tourism development and other economic activities and local community development.

The main conflict in this area occurs between the protection of nature and natural values and tourism and other economic activities. Based on the underlying principles of sustainable development, it is essential to establish a balance between sustainable protection of values and resources and sustainable development of the area.

This can be accomplished by establishing appropriate regimes for the protection and use of space with natural values and resources, sustainable development of tourism and other economic activities, controlled spatial planning, stimulating corporate social responsibility and natural values and resources protection management [2], [3].

There can also be a conflict between the local population and the protection of natural values and resources, as well as between the local population and tourism.

The basic principle for mitigating these potential conflicts is the realization of benefits for the local community, as follows:

- Inclusion of the local population in activities on the protection and presentation of natural resources (water, forests, etc.);

- Providing compensation or compensation programs (primarily in tourism) for damage caused by restrictions within the regime of protection of natural resources;

- Contribution to the local economy, promotion and use of local products in tourist offer, and education of the population to promote natural values and involve them in the provision of tourist and complementary services;

- Establishing a balance between the benefits of tourism and other economic activities crucial for the maintenance and development of the local community [4].

Realization of this principle implies undertaking of a number of actions, primarily related to infrastructural equipping of the area to meet the needs of the local population and providing new jobs and additional sources of income for the rural population. The feedback effects would be the preserved demographic resources of rural areas and the network of settlements, developed activities complementary to the protection and use of space, and the involved local population in the protection, arrangement, and promotion of natural and cultural resources and the values of the area.

\section{SUSTAINABLE TOURISM DEVELOPMENT CONCEPT}

One of the basic development opportunities of the subject area is sustainable tourism development. It implies the development of a tourism economy in line with environmental capacities. On the one hand, the goal of this concept is to familiarize a large number of visitors with the tourist values of this area and to activate other complementary activities that would enable tourism development or its products (animal husbandry, forestry, production of healthy food, beverages, textiles, etc.), while, on the other hand, these activities should be organized in a way that does not endanger the ecological balance of the area and the rich flora and fauna [2]. 
The basic concept of tourism development is based on the functional networking of the tourism industry and activities at the broader regional level and the internal organization of the tourism industry and activities at the local level.

The dominant tourist products and tourism forms in this area will be based on rich natural and anthropogenic resources and the values of the area: mountains; lakes and rivers; cultural and historical heritage; climate benefits - health-rehabilitation tourism; ethnographic and ethnic diversity - event tourism; tradition and villages - rural-ethno tourism; geostrategic position and traffic connections - transit tourism; natural and anthropogenic rarities and phenomena educational and ecological tourism; accommodation capacities - congress tourism; hunting and fishing tourism [4].

All forms of tourism products should work harmoniously, i.e. potential users should combine several aspects of tourism [5]. The unity of content is of a distinct regional character and implies the existence of common itineraries with neighboring municipalities and regions. At the same time, the internal organization of tourism requires the involvement of conventional and traditional production into a single economic system that would allow greater employment of the local population, rise in competitiveness, and slow down demographic loss in certain parts of the area (especially in the countryside). The basic starting point is the activation of all the potentials of the planned area so that the user first gets to know about the advantages and tourist values of this region, reach the destination through organized or individual and comfortable transport, find accommodation in high-quality facilities, spend time rich in content, and return. The need for education of managers and population about the role and significance of tourism, marketing breakthrough on the Serbian and European market, increased traffic accessibility by building state and local roads and quality accommodation are a prerequisite for the realization of this concept [4].

For the successful implementation of the planned concept of tourism development in the area of SNR Uvac, the following priorities for tourism development have been defined:

- Full valorisation and better organization of the use of tourism potentials and tourist offer - identity of space and competitiveness;

- Networking with neighboring and far regions in the unique tourist zone of Western Serbia - inter-municipal cooperation;

- Reconstruction, adaptation, and construction of necessary transport infrastructure that would enable greater accessibility to local and regional tourist sites;

- Reconstruction and construction of accommodation capacities in attractive tourist destinations (centers, secondary centers, and points);

- Establishment of visitor centers, entry and info points;

- Implementation of permanent, multidisciplinary education of experts and population for tourism development;

- Promotion of marketing tourism through promotional and information programs; at the same time, insisting on existing tourism brands and the promotion of new ones [4].

\section{CONCLUSION}

The spatial plan represents an effective tool for solving contradictions and conflicts between environmental protection and tourism. In this way, this contradiction can be transformed into the interdependence of tourism development and nature protection, because it should be noted that tourism is an activity whose development is directly influenced by the conditions in the natural environment [2]. 
It is necessary to emphasize that an important prerequisite for increasing efficiency in implementing planned decisions on sustainable tourism involves adequate and continuous information and involvement of key stakeholders and the community in the spatial and environmental planning process.

In the area of the SNR Uvac Spatial Plan, tourism should be a more important economic branch in the future. Tourism development will be realized in accordance with the requirements of preserving natural resources and values, while respecting the interests of local communities. It is necessary to secure the area opening in terms of traffic and integrate the tourist offer of the area with the regional offer. Priority is the conception, organization, promotion, and completion of specific tourist offer and attractive programs in the planned area, completion of public utility and tourist infrastructure for the needs of tourism development, increasing standards of services within existing and planned tourist capacities, activation of the local population in the rural area and its housing fund for tourism development.

\section{REFERENCES}

[1] Maksin, M., Pucar, M., Milijć, S., Korać, M. (2011) Sustainable Tourism Development in the European Union and Serbia, Institute for Architecture and Urban \& Spatial Planning of Serbia, Belgrade (in Serbian)

[2] Eagles, P.F.J., McCool S., Haynes, C.D. (2002) Sustainable Tourism in Protected Areas: Guidelines for Planning and Management, WCPA, IUCN, Gland, Switzerland, Cambridge, UK, UNEP and the WTO.

[3] Nikolić, S. (2006) Tourism in protected natural resources of Serbia, Institute for Nature Protection, Serbia, Belgrade (in Serbian)

[4] Spatial Plan for Special Purpose Area of the Special Nature Reserve Uvac, Official Gazette of the Republic of Serbia, No. 83/2010 (in Serbian)

[5] Tourism Development Strategy of the Republic of Serbia for the period from 2016 to 2025, Official Gazette of the Republic of Serbia, No. 98/2016 (in Serbian)

[6] Official website of the Special Nature Reserve Uvac - http://www.uvac.org.rs/specijalnirezervat-prirode-uvac 